УДК 347.4

DOI https:/ / doi.org/10.32837/ yuv.v0i4.976

В. Никифорак,

кандидат юридичних наук,

доцент кафедри приватного права

Чернівецького національного університету імені Юрія Федьковича

\title{
МЕЖІ СВОБОДИ ДОГОВОРУ КРІЗЬ ПРИЗМУ РОЗУМНОСТІ, СПРАВЕДЛИВОСТІ ТА ДОБРОСОВІСНОСТІ
}

Попри всю беззаперечність та надзвичайну важливість принципу свободи договору, який $€$ одним із фундаментальних принципів приватноправових відносин, задекларована законом свобода договору неодмінно повинна мати свій обсяг та відповідні межі. Зрозуміло, що обумовленість таких меж може мати під собою різне підгрунтя, проте, першочергово означена необхідність встановлення меж свободи договору прямолінійно залежить від належної реалізації таких загальних засад цивільного права як розумності, справедливості та добросовісності [1]. В цілому, вказані принципи є «мірилом, «лакмусовим папірцем», «цементуючою ланкою» розвитку і становлення майнового обороту» [2] в сучасному суспільстві.

Проблемами свободи договору загалом, а також меж іï реалізації зокрема, займалися чимало вітчизняних та зарубіжних цивілістів, серед яких В.С.Бєлих, О.А.Беляневич, М.Є.Василенко, Н.Ю.Голубєва, А.В.Луць, В.В.Сергієнко, Р.Ю.Ханик-Посполітак та багато інших. Водночас у працях цих вчених питання меж свободи договору через призму розумності, добросовісності та справедливості в комплексі раніше не розглядалося.

Метою цієї статті є надання відповіді на питання про чинники обмеження договірної свободи та їх обумовленість такими засадами цивільного права як розумність, добросовісність та справедливість.
На наш погляд, проблема меж свободи договору повинна розглядатися щонайменше 3 двох сторін. 3 одного боку, слід однозначно погодитись із тим, що свобода договору не безмежна, адже завжди існує об'єктивна потреба в ї обмеженні в цілях захисту публічних інтересів, інтересів слабкої сторони договору, інтересів кредиторів тощо [3]. 3 іншого боку, практика свідчить, що суди досить часто формально застосовують норми зобов'язального права, чим необгрунтовано зазіхають на свободу договору, а також на такий принцип (формально не проголошений Цивільним кодексом України, але міститься в багатьох нормах), як принцип стабільності цивільного обороту. 3 цим пов'язана практика визнання договорів неукладеними або визнання окремих умов договорів незаконними 3 причин невідповідності їх певним імперативним нормам цивільного права.

Якщо ж більш грунтовно прослідкувати реалізацію свободи договору в цивільному праві як основній приватно-правовій галузі, якій даний принцип властивий, то можна з'ясувати, що винятками із загального принципу свободи договору, як слушно зазначають В.В. Сергієнко та Д.П. Півовар, $€$ випадки, коли [4]: 1) укладення договору є обов'язковим (публічний договір, виконання оборонного замовлення тощо); 2) укладення договору певного типу може бути заборонено тим або іншим суб'єктам, що випливає, як правило, з природи діяльності, що оформ- 
ляється відповідними договорами; 3) будь-яка із сторін договору позбавлена можливості брати участь у формуванні його умов (до прикладу договору приєднання, договору на користь третіх осіб). Не важко помітити, що в означених авторами випадках акцент робиться саме на добросовісності, яка й покликана захистити інтереси слабшої сторони i, тим самим, забезпечити належну реалізацію принципу свободи договору.

На захисті інтересів осіб наголошує і Н.Ю.Голубєва, яка, зокрема, зазначає, що «можливість винятків з принципу свободи договору зумовлена необхідністю захисту державою суспільних інтересів загалом, прав споживачів зокрема, особливо в тих сферах економіки, які $€$ природними монополіями або ж в яких $є$ можливим порушення допустимих меж реалізації цивільних прав особами, які займають на ринку домінуюче становище» [5]. Якщо таку позицію розглянути детальніше, то можна дійти логічного висновку про залежність меж законодавчих обмежень принципу свободи договору від економічної ситуації в державі. Адже, під час економічної кризи держава завжди дотримується жорсткішої законодавчої політики стосовно обмеження договірної свободи, що в свою чергу пояснюється нагальною необхідністю усунення передумов або наслідків такої кризи. Зрозуміло, що в такому разі діятиме примат колективних інтересів над індивідуальними. I навпаки, якщо негативні фактори в державі відсутні, а економіка характеризується стабільністю, то першочерговою стає ідеологія особистої свободи та індивідуалізму, що безумовно тягне за собою зменшення законодавчих обмежень договірної свободи [6]. Обмеження наведеного характеру, на нашу думку, обумовлюються критеріями розумності.

Найбільш яскраво обмеження договірної свободи прослідковується в цивільному праві, і це природно. На підставі проведеного аналізу положень цивільного законодавства України, а також доктрини цивільного права України було з'ясовано, що обмеження свободи договору в цілому можна класифікувати на дві групи: 1) обмеження свободи щодо укладення цивільно-правового договору; 2) обмеження свободи щодо виду, форми та змісту цивільно-правового договору.

Перша група, яка стосується обмеження свободи стосовно укладення цивільно-правового договору, полягає в покладенні законом обов'язку на особу щодо укладення договору у прямо визначених випадках. Тобто в даному разі мова вже абсолютно не йде про будь який вільний вияв волі, про іiі автономію. Зокрема, згідно законодавства такими «обов'язковими договорами» $€$ : 1) публічний договір; 2) договір приєднання; 3) договір за державним замовленням; 4) типовий договір; 5) попередній договір.

Стосовно публічного договору законом встановлені наступні обмеження: комерційній організації забороняється надавати переваги окремим особам при укладенні публічного договору, встановлювати неоднакові ціни для своїх споживачів, а при необгрунтованому ухиленні від укладення публічного договору споживач може примусити іï до цього або вимагати відшкодування завданих таким ухиленням збитків у судовому порядку.

У передбаченому ч.1 ст.634 ЦК України договорі приєднання, обмеження свободи договору простежується в тому, що сторона, яка приєднується до такого договору, не може внести будь-яких змін до самого договору, не може претендувати на переговори щодо «індивідуальних» умов договору і т.п. Слід визнати, що в даному разі договірна свобода також зберігається, хоча й в обмеженому вигляді. До речі, договори приєднання властиві не лише романо-германській правовій системі. В країнах англо-американської цивільно-правової сім’ї договори приєднання отримали назву «продиктовані договори», відповідно до яких одна сторона (зазвичай монополіст у відповід- 


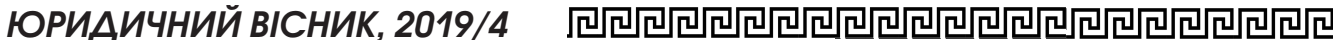

ній галузі) наказує свої умови контрагенту. В Англії, США та інших країнах вони називаються «договорами в стандартній формі» (standardform contracts) [7]. Будучи розробленими однією стороною, умови такого договору можуть бути прийняті або відкинуті споживачем. Таким чином, останній (споживач) має формальне право відмовитися від укладення невигідного для нього договору. Однак реалізація цього права ускладнена і практично неможлива, оскільки в силу економічної нерівності контрагент фактично не має можливості вибору і змушений нерідко погоджуватися на такі умови [7].

Наступним законодавчим обмеженням свободи договору $€$ приписи ч.4 ст.183 ГК України, відповідно до яких ухилення від укладення договору за державним замовленням $€$ порушенням господарського законодавства і тягне за собою відповідальність, передбачену Господарським кодексом та іншими законами України. Таким чином, закон прямо приписує суб'єкту обов'язковий порядок укладення договору, а ухилення від цього тягне за собою застосування господарських санкцій відповідно до ст. 218 ГК Украіни. Наведений договір обумовлюється публічним інтересом, який і встановлює винятковий випадок, коли сторона зобов'язується укласти господарський договір без власного на те волевиявлення, а отже обумовити подібний випадок обмеження договірної свободи критеріями розумності, добросовісності чи справедливості неможливо.

Подібним законодавчим обмеженням договірної свободи виступає положення абз.4 ч.4 ст.179 ГК України, яке визначає, що при укладенні господарських договорів сторони можуть визначати зміст договору на основі типового договору, затвердженого Кабінетом Міністрів України, чи у випадках, передбачених законом, іншим органом державної влади, коли сторони не можуть відступати від змісту типового договору, але мають право конкретизувати його умови. Такі типові договори можуть застосовуватися і в цивільному праві, а саме при укладенні публічних договорів та договорів приєднання. Попри те, що типові договори спрямовані на однакове та ефективне врегулювання договірних відносин осіб, все ж вони мають і свою негативну сторону. Досить часто на практиці умови таких договорів ставлять одну із сторін у вкрай невигідне становище порівняно 3 іншою. Щоб хоч якось врівноважити дану ситуацію у міжнародному законодавстві, зокрема, законодавстві Європейського Союзу та держав-членів ЄC було розроблене поняття «несправедливі умови в договорах» (unfair term in contract). Зокрема, відповідно до ч.1 ст.3 Директиви Ради ЄC № 93/13/ ЄЕС від 5 квітня 1993 року «Про несправедливі умови в договоpax зі споживачами» [8] (яка перебуває у переліку тих міжнародних актів, які підлягають імплементації у чинне законодавство України [9]) умови договору, які не обговорювалися індивідуально, визнаються несправедливими, якщо всупереч вимогам добросовісності вони призводять до значного дисбалансу щодо прав та обов'язків сторін, які випливають 3 договору, на шкоду споживачеві. Окрім цього, поняття «несправедливі умови в договорах» закріплено у ст. 4.110 Принципів європейського договірного права. У вказаній статті закріплено: «Сторона може оспорювати умову, яка не була індивідуально обговорена, якщо, всупереч вимогам добросовісності та чесної ділової практики, вона призводить до істотного дисбалансу в правах та обов'язках сторін, які виникають за договором, завдають шкоди стороні, беручи до уваги природу майбутнього виконання договору, а також всі інші умови договору та обставини на час укладення договору».

Порівнюючи положення Директиви 93/13/ EЕС з Принципами, можна зробити висновок, що несправедливою $є: 1)$ така умова договору, яка не була попередньо погоджена з контрагентом. Погодженою вважається умова, яка була 
предметом переговорів між сторонами. Такі переговори можуть проходити шляхом складання проекту договору однією стороною, в який можуть вноситися зміни другою стороною або прийматись другою стороною без змін. У будьякому випадку, вирішення питання: чи умови договору були погоджені 3 контрагентом - залежатиме від конкретних обставин укладення договору; 2) умова, яка всупереч вимогам добросовісності та чесної ділової практики спричиняє істотний дисбаланс у правах та обов'язках сторін [10].

Досить спірним, на нашу думку, видається питання про обмеження свободи договору за попереднім договором. Відповідно до ст.635 ЦК України попередній договір - це угода, сторони якої зобов'язуються протягом певного строку укласти договір у майбутньому (основний договір) на умовах, встановлених попереднім договором. Однак договір про наміри i, зокрема, протокол про наміри, в якому відсутнє узгоджене волевиявлення сторін щодо надання йому сили попереднього договору, таким не вважається. Таким чином, набуває розвитку норма ст. 626 ЦК України про договір як домовленість та ст. 627 ЦК України про волевиявлення сторін як обов'язкову складову свободи договору [11].

Другу групу обмежень, як вже було зазначено вище, складають обмеження свободи стосовно виду, форми та змісту договору, які обумовлюються суб'єктним складом правовідносин, предметом та цілями укладення такого договору. Зокрема, сторони не можуть повністю на власний розсуд (свавільно) укладати цивільно-правові договори, навіть якщо це прямо не суперечить законодавству.

По-перше, укладення цивільно-правового договору повинно здійснюватися належними суб'єктами. По-друге, варто пам'ятати, що межі договірної свободи дуже тісно кореспондують 3 інститутом фіктивних та удаваних правочинів. Таким чином, саме природа договірних цивільних правовідносин визначає належну договірну конструкцію. Інакше можна вести мову про удаваність, фіктивність або ж недійсність правочину (договору).

Договірна свобода сторін цивільно-правового договору обмежується також способом укладення (формою) договору, а саме обмежена обов'язковістю письмової форми договору, а також його нотаріального посвідчення у прямо передбачених законом випадках та допустимістю його укладення шляхом мовчання лише у випадках, прямо передбачених законом або домовленістю сторін (ст. ст. 205, 208, 209, 210 ЦК України).

Прикладом умови цивільно-правового договору, якою обмежується свобода однієї із сторін угоди може слугувати так зване «пріоритетне право» («переважне право»), прикладів якого чинне законодавство містить чимало. Так, до прикладу, ст.362 ЦК України встановлено, що у разі продажу частки у праві спільної часткової власності співвласник має переважне право перед іншими особами на їі купівлю за ціною, оголошеною для продажу, та на інших рівних умовах, крім випадку продажу з публічних торгів. На перший погляд наявність вказаних переважних прав видається несправедливою у відношенні до тих суб'єктів, права та інтереси яких не $€$ переважними. Однак, насправді така «умовна несправедливість» переважних прав обгрунтовується наявністю певних, законодавчо визначених, чинників, які передують виникненню даних прав, а отже і підтверджують їх допустимість з точки зору права.

Не менш цікавим та допустимим, 3 точки зору положень законодавства країн як англо-американської, так і романо-германської цивільно-правових систем, обмеженням принципу свободи договору $€$ так звані «обмежувальні умови» договору комерційної концесіі, більш відомого світу як франчайзинг. Такі умови встановлені статтею 1122 ЦК України, згідно якої у договорі комерційної концесії можуть бути передбачені особливі (обмежувальні) умови, а саме: 1) обов'язок правоволодільця не надавати іншим суб'єктам аналогічні 


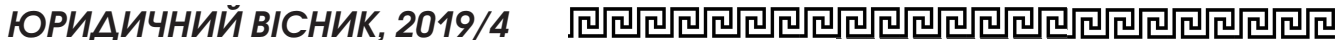

комплекси прав для їх використання на закріпленій за користувачем території або, навіть, утримуватися від власної аналогічної діяльності на вказаній територіi; 2) обов'язок користувача не створювати конкуренцію правоволодільцеві на територіі, на яку поширюється чинність договору, зокрема, щодо підприємницької діяльності, яку здійснює користувач з використанням виключних прав правоволодільця; 3) обов'язок користувача не отримувати аналогічні права від конкурентів (в тому числі потенційних) правоволодільця; 4) обов'язок користувача узгоджувати 3 правоволодільцем місце розташування комерційних приміщень для продажу товарів чи надання послуг, а також їх інтер'єр та екстер'єр. Попри вказані положення, кодекс визначає також перелік умов, які $є$ неприпустимими в контексті обмеження прав сторін договору комерційної концесіі з точки зору їх справедливості та добросовісності. Зокрема, умова договору, за якою правоволоділець вправі визначати ціну товару (робіт або послуг), або встановлювати верхню чи нижню межу такої ціни, є нікчемною. 3 аналогічних причин має бути нікчемною умова договору, відповідно до якої користувач має право продавати товари (виконувати роботи, надавати послуги) виключно певній категорії покупців (замовників) або виключно покупцям (замовникам), які мають місцезнаходження (місце проживання) на території, визначеній у договорі.

Обмеження свободи договору можуть бути продиктовані і специфікою об’єкта (предмета) договору. Зокрема, об'єктом договору не можуть бути речі, які законом або іншим актом вилучені з обігу. Крім того, деякі об’єкти, зазначені в законі або в передбаченому в ньому порядку, можуть належати тільки певному колу осіб, або особам, які отримали спеціальний дозвіл. Нормативні приписи стосовно вказаних об'єктів містяться у Постанові Верховної Ради України від 24.01.1995 р. «Про право власності на окремі види майна».

Окремо треба розглянути можливість обмеження досліджуваного принципу категоріями справедливості та моралі. 3 цього приводу О.А.Беляневич зазначає, що інститутами, які істотно обмежують договірну свободу слід вважати: 1) відповідно до ст. 627 ЦК - вимоги розумності та справедливості, яких мають дотримуватися учасники договірних правовідносин; 2) відповідно до ч. 1 ст. 203 ЦК - моральні засади суспільства. Крім того, в окремих актах чинного законодавства такими обмежувачами називаються «суспільний порядок», «публічний порядок», «публічні інтереси», «принципи гуманності та моралі», «моральні засади суспільства». Застосування в судовій практиці саме таких обмежень свободи цивільно-правового договору є найбільш складним через абстрактність формулювання та оціночний характер вказаних категорій [12], внаслідок чого суди по-різному застосовують ці категорії, виходячи із фактичних обставин конкретної справи, а також виходячи з доказової бази кожного з учасників судового процесу.

Вважається, що філософська основа осмислення свободи полягає в іï діалектичному розумінні як похідного від обмежень, що дозволяють окреслити межі цього явища і, тим самим створюють його. На думку німецького філософа Йоганна Готліба Фіхте, кожна конкретна людина «... повинна обмежити свою вільну діяльність таким чином, щоб інші могли жити, а інші, в свою чергу, свою вільну діяльність так, щоб могла жити вона» [13]. Отже, свобода - це зворотна сторона правових обмежень. Чим більше обмежень та заборон, тим менше свободи!

$\mathrm{У}$ той же час у свободи є обмеження, межі. В цьому відношенні видається справедливим вислів І.П.Малінової про те, що «нічим не обмежена свобода унеможливлює сам вибір, оскільки відсутність зовнішніх обмежень не дозволяє сформулюватися внутрішнім а, отже, виключає самовизначеність у вчинку» [14]. Натомість імперативні норми доволі часто убезпечують суб'єктів права від настання несприятливих для них наслідків. При цьому обмеження, 
визначені законом, повинні відповідати принципам права, а отже, не порушувати права осіб. Лише в такому випадку вони не матимуть негативної реакції, належно сприйматимуться суспільством. Розумність як підстава обмеження свободи обгрунтовувалася свого часу ще Г.В.Ф. Гегелем. Зокрема, він зазначав, що впертий наполягає на своій позиції лише тому, що це його правда, він наполягає на ній без розумної підстави, тобто без того, щоб його намагання були чимось, що має загальну цінність [15].

Таким чином, підсумовуючи все вище викладене, можна стверджувати, що існує ряд причин, які спонукали законодавця встановити обмеження дії принципу свободи договору. Але загалом усі ці причини пов'язані 3 необхідністю дотримання балансу інтересів окремих осіб і всього суспільства в цілому, і метою обмежень принципу свободи договору в кінцевому рахунку $€$ нормальне (належне) функціонування економіки, безперервний розподіл (обіг) товарів, робіт і послуг серед суб'єктів цивільних правовідносин, а також дотримання загальних засад приватного права - розумності, добросовісності та справедливості.

У статті проаналізована необхідність законодавчого обмеження свободи договору. При иьому обтрунтовується, що необхідність встановлення меж свободи договору прямолінійно залежить від належної реалізаиії таких загальних засад ицвільного права як розумності, справедливості ma добросовісності.

На підставі проведеного аналізу положень цивільного законодавства України, а також доктрини ичивільного права України було з'ясовано, щз обмеження свободи договору в изілому можна класифікувати на дві групи: 1) встановлення меж свободи щодо укладення ицвільно-правового договору; 2) обмеження свободи щодо виду, форми та змісту цивільно-правового договору.
Перша група чинників обумовлюе наявність таких «обов'язкових» договорів як: 1) публічного договору; 2) договору приєднання; 3) договору за державним замовленням; 4) типового договору; 5) попереднього договору. Доцільність встановлення меж договірної свободи щодо наведених договорів обтрунтовується в більшій мірі критеріями справедливості та добросовісності.

Друга група обмежень обумовлюється суб'єктним складом правовідносин, предметом та цілями укладення иивільно-правового договору, а отне має в своїй основі приници розумності. У статті встановлено, що межі договірної свободи тісно кореспондують з інститутом фіктивних та удаваних правочинів.

Окремо доводиться доцільність обмеження договірної свободи иляхом визначення понять «переважне право» та «обмежувальна умова». «Умовна несправедливість» переважних прав обтрунтовується наявністю певних, законодавчо визначених, чинників, які передують виникненню даних прав, а отже $і$ підтверджують ï допустимість з точки зору права. В свою чергу, можливість встановлення обмежувальних умов у договору комериійної концесї обумовлюється критеріями справедливості та добросовісності.

Як висновок в статті обтрунтовується положення про те, що усі причини обмеження свободи договору пов'язані з необхідністю: 1) дотримання балансу інтересів окремих осіб i всього суспільства в ијлому; 2) безперервного розподілу (обігу) товарів, робіт i послуг серед суб'єктів изивільних правовідносин; 3) дотримання загальних засад приватного права розумності, добросовісності та справедливості.

Ключові слова: свобода договору, межі свободи, добросовісність, розумність, справедливість, переважні права, обмежувальні умови. 


\section{Nykyforak V. LIMITS OF CONTRACT FREEDOM FROM THE POSITION OF RATIONALITY, JUSTICE AND INTEGRITY}

The article under studies reveals the necessity of legislative restriction in the contract freedom. It substantiates that the above necessity directly depends on proper implementation of such fundamentals of Civil Law as rationality, justice and integrity.

Based on the analysis of the provisions of the Ukraine's civil legislation, as well as on the Ukrainian Civil Law doctrine, it has been ascertained that the restriction of the contract freedom may be classified into two groups: 1) establishing the limits of freedom regarding the conclusion of a civil contract; 2) restriction of freedom regarding the type, the form and the content of a civil contract.

The first group of factors presupposes such "mandatory" contracts as : 1) a public contract;2) a contract of accession; 3) a government contract; 4) a model contract; 5) a preliminary contract. The expediency of establishing restrictions in the above contracts is mostly substantiated by the criteria of justice and honesty.

The second group of restrictions arises out of the composition of legal relations, the subject and the objectives of concluding a civil contract, and, consequently, rests on the principle of rationality. The article lays particular emphasis on the fact that the restrictions of the contract freedom are very closely related to the notions of fictitious and sham transactions.

In addition, the necessity of introducing restrictions into the contract freedom has been proved by means of defining the notions of "the priority rights" and "restricting condition". "The conventional injustice" of the priority rights is explained with the help of certain legislatively determined factors that proceed the emergence of the above-mentioned priority rights. Hence, they may be considered as acceptable from the point of view of law. What is more, the possibility of establishing restrictions in a contract of commercial concession is caused by the criteria of justice and integrity.

The article concludes that all the reasons that make up for restricting the contract freedom are associated with the necessity of: 1) keeping up a balance between the interests of certain individuals and the society on the whole; 2) continuous distributing the goods and services among the participants of legal relations; 3) keeping up to the universal requirements of Private Law - the principles of rationality, integrity and justice.

Key words: contract freedom, freedom restrictions, rationality, integrity, justice, priority rights, restricting conditions.

\section{Література}

1. Воловик О.А. Еволюиія мети договірного права крізь призму економічного підходу: (історія та сучасні тенденції). Вісник Вищої ради юстиції. 2013. №2. С.134.

2. Полич С.Б. Принщипы гражданского права - оценочные категории? Проблемы права. 2015. №4 (52). С.136.

3. Брагинский М.И., Витрянский В.В. Договорное право: в 2 кн. Кн. 1: Общие положения. 2-е изд., испр. М.: Статут, 2000. C. 159 .

4. Сергієнко В.В., Півовар Д.П. Порушення принципів цивільного права при регулюванні відносин укладених типовими договорами. Wschodnioeuropejskie Czasopismo Naukowe (East European Scientific Journal). 2015. №4. C.22.

5. Голубєва Н.Ю. Свобода договору як принции цивільного права. Актуальні проблеми держави і права. 2009. Випуск 51. C.70.

6. Василенко М.Е. Свобода договору, обмежена публічним порядком та моральними засадами суспільства, у континентальному иивільному законодавстві. Порівняльно аналітичне право. 2014. №8. C.66.

7. Белых В.С. Принцип свободы договора в английском праве: доктрина и судебная практика. Право и государство. 2015. №4. C.33.

8. Council Directive 93/13/ EEC of 5 April 1993 on unfair terms

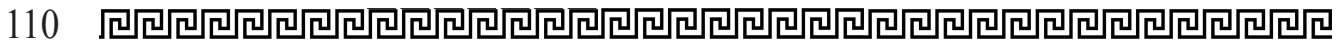


in consumer contracts. URL: http:// eur-lex.europa.eu/legal-content / EN / TXT $/$ ? uri $=$ celex\% 3 A31993L0013

9. Розпорядження Кабінету Міністрів України «Про схвалення розроблених Міністерством економічного розвитку i торгівлі планів імплементації деяких актів законодавства ЄC» від 4 березня 2015 p. URL: http: / / zakon2.rada.gov.ua/ laws / show / 164-2015-p

10. Ханик-Посполітак Р.Ю. Поняття «несправедливі умови в договору». Наукові записки. Юридичні науки. 2000. Том 64. С.104.

11. Басай О.В. Принциипи цзивільного права України: теорія і практика: монографія. Наи. ун-т «Одес. юрид. акад.». Івано-Франківськ: Сімик, 2013. С.268.
12. Беляневич О.A. Принцуип свободи договору за Цивільним та Господарським кодексами України. Вісник Київського наи. ун-ту імені Тараса Шевченка. 2004. №60/52. С.66.

13. Забоев К. Ю. Правовые и философские аспекты гражданско-правового договора. СПб.: Юридический центр-Пресс, 2003. C.80-85

14. Малинова И.П. Классическая философия права. Материалы лекиий. Екатеринбург: Изд-во УрГЮА, 1997. С.23.

15. Мічурін Є. О. Обмеження майнових прав фізичних осіб (теоретико-правові аспекти): Монографія. Х.: Юрсвіт, НДІ Приватного права $і$ підприємництво АПрН України, 2008. C.217. 